\title{
SIGNALS FLOWING FROM MATURE TISSUES TO SHOOT APICAL MERISTEM AFFECT PHYLLOTAXIS IN CONIFEROUS SHOOT
}

\author{
AlicJa BANASIAK, BEATA ZAGÓRSKA-MAREK \\ Institute of Botany, Wrocław University \\ Kanonia 6/8, 50-328 Wrocław, Poland \\ e-mail: beata@biol.uni.wroc.pl
}

(Received: December 12, 2005. Accepted: March 29, 2006)

\begin{abstract}
Axial homodromy in growing shoots of perennial plants with spiral phyllotaxis is the case when the chirality of phyllotactic pattern does not change in consecutive growth increments of the same axis. In conifers such as $P i$ cea or Abies this rule is strictly observed, except for the rare cases of discontinuous phyllotactic transitions. In Torreya, however, the chirality changes, at random, every year. The pattern of primordia packing, executed by vegetative shoot apical meristem (SAM), depends in Torreya on their identity. The primordia of bud scales are initiated in the decussate and those of needles in bijugate spiral pattern. The decussate, achiral i.e. neutral pattern always precedes the formation of new spiral pattern and thus facilitates random selection of its chiral configuration. Periodic change in organ identity cannot itself be responsible for the special behavior of Torreya, because in other conifers it also exists. There is, however, one important difference: in Torreya, when the initiation of bud scales begins at SAM, the distance between differentiated protoxylem and the initiation site gradually increases, while in other conifers it remains constant and small. In Torreya, at this phase of development, the rate of xylem differentiation and the rate of organogenesis become uncoupled. Closer anatomical examination shows that the decussate pattern in a bud scale zone develops slowly suggesting gradual decrease of the putative signal flowing acropetally from differentiated protoxylem, responsible for positioning of primordia. We hypothesize that in the absence of this signal SAM starts acting autonomously, distributing primordia according to their identity only. A constant presence of the signal in other conifers assures the continuation of the same phyllotactic pattern throughout the period of bud scale formation, despite the change in organ identity.
\end{abstract}

KEY WORDS: phyllotaxis, auxin, shoot apical meristem, vascular system, conifers, leaf primordia.

\section{INTRODUCTION}

The shoot apical meristem (SAM) initiates the primordia of lateral organs in a very regular manner. Emerging pattern of their spatial distribution is called phyllotaxis. The studies on the causes of various phyllotactic patterns have long history, reaching back to the XIX century (Hofmeister 1868; Airy 1873; Schwendener 1878). Both theoretical and experimental approaches resulted in many theories, the majority of which refers to the autonomy of SAM in creating organographic order, pointing out the significance of the chemical (Richards 1951; Veen, Lindenmayer 1977; Schwabe, Clewer 1984) or physical (Adler 1974; Ridley 1982; Douady, Couder 1996; Fleming et al. 1997) interactions between youngest primordia. Some other theories suggest, that signals decisive for placing primordia, determining their initiation site, may flow from far away located, already differentiated tissues, perhaps through the vascular system (Girolami 1953; Larson 1975, 1977). Larson has shown that in Populus some important changes in ar- chitecture of primary vascular system take place well before any symptoms of these changes could be detected in corresponding pattern of primordia initiation on the SAMs surface.

In accordance with one of the latest ideas, existing leaf primordia sythesize auxin, which is transported acropetally in protodermal cells of L1 layer in a process of polar auxin transport (PAT). Auxin presence in organogenic zone of the meristem induces organogenesis at the site of its highest concentration (Stieger at al. 2002; Reinhardt et al. 2003). Differences in auxin level result from its depletion by youngest primordia and from reversals of PAT within SAM's cells. Auxin is transported towards the summit of SAM until new primordium is initiated. Then the reversal of PAT occurs in the cells above the emerging primordium: they start transporting auxin towards its tip - away from the apex summit. When the distance between growing apex and the primordium is big enough, cells located adaxially, above the future primordial crease, change again the direction of auxin flow - now towards the summit 

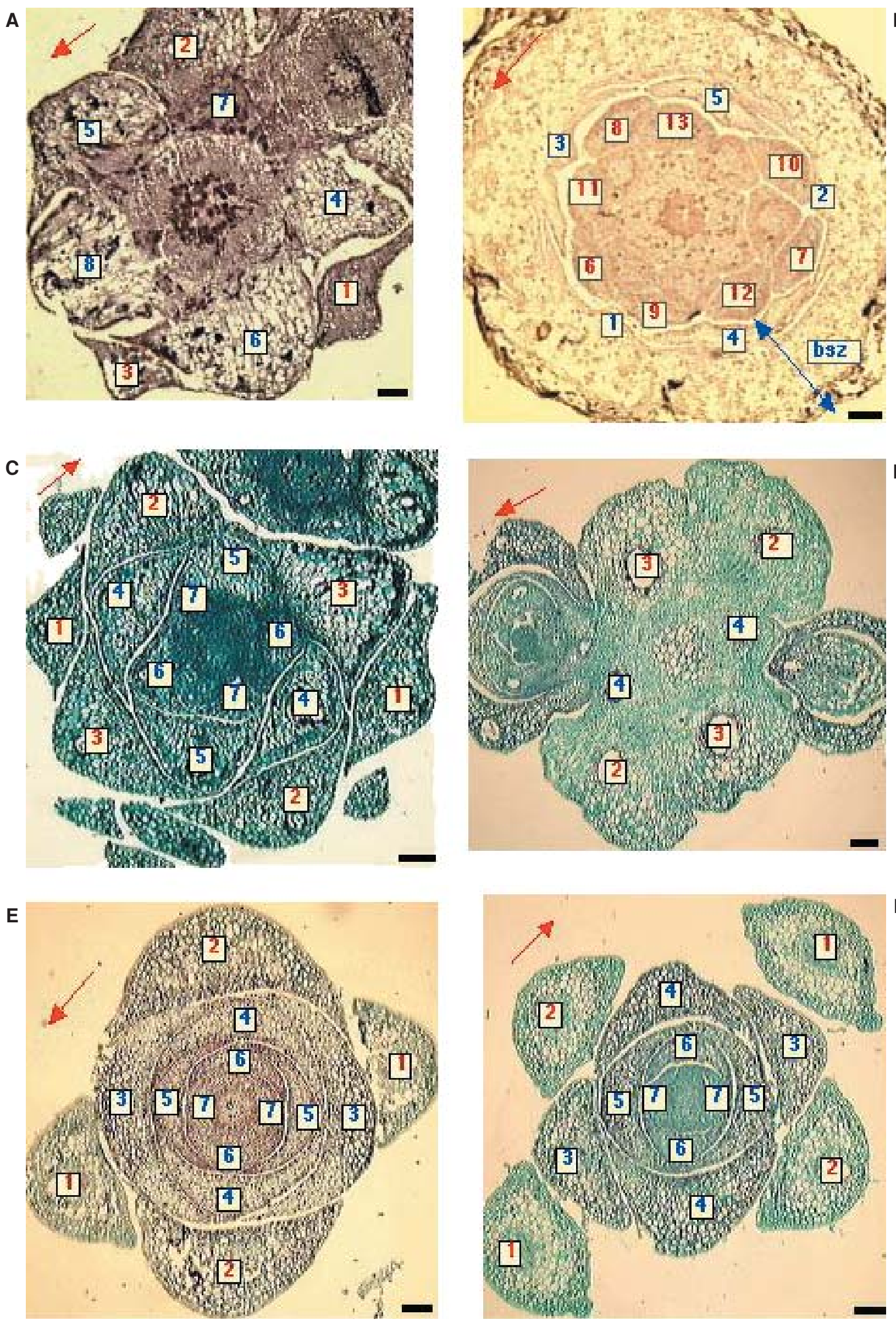

Fig. 1. Transverse sections through the young vegetative shoots. A - Taxus baccata, B - Abies concolor, C - Cephalotaxus fortunei, D-E - Torreya nucife$\mathrm{ra}$. The successive foliage leaves are numbered with red color, the successive bud scales - with blue color. The red arrow shows the course of ontogenetic helix. Scale bar $-0.5 \mathrm{~mm}$. 
(Jönsson et al. 2006). The nature of the signal for the periodic redistribution of auxin transporters, such as PIN and AUX, within a given cell is unknown. It is also uncertain, whether the differences in auxin concentration at the SAM are solely due to the events taking place in the apex itself. Even the source of transported auxin is uncertain - primordia conceptually are the producers and the users of the auxin. Nonetheless, based on the changes in polarized auxin transport within L1 layer of SAM, already two new models of phyllotaxis have been proposed (Jönsson et al. 2006; Smith et al. 2006).

The significance of plant model systems, such as Arabidopsis, for phyllotactic research cannot be underestimated. But other plants like Magnolia, where rich variety of floral phyllotactic patterns and transitions is present, are also interesting (Zagórska-Marek 1994; Zagórska-Marek, Stoma 2005). Especially rewarding are conifers with their unlimited, monopodial growth, which in case of axis of any order may continue for many years in a result of the activity of one, individual meristem. The conifers with spiral phyllotaxis and predetermined growth of the shoot have been used in studies on the degree of SAM's autonomy in setting up the organographic order of initiated primordia. By determining chiral configuration of phyllotactic pattern in

A

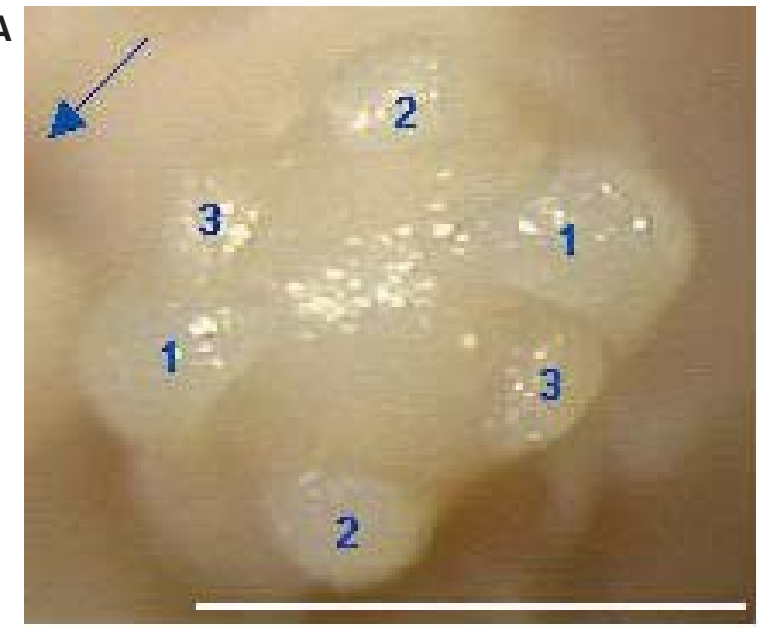

C

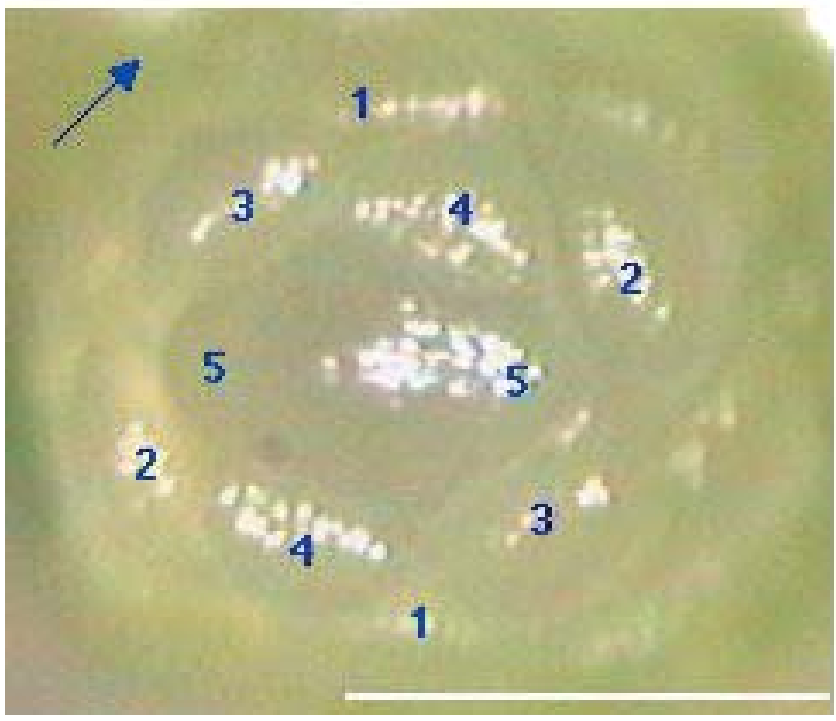

one shoot's consecutive annual increments, it has been proven, that periodically active SAM, initiating primordia, is less autonomous in Abies than in Torreya. In the first case axial homodromy was observed - chiral configuration of phyllotactic pattern was perpetuated from year to year ( $\mathrm{Za}$ górska-Marek 1985), in a second - the chirality of the pattern was established every year at random (Banasiak, Zagórska-Marek 1998; Banasiak, Zagórska-Marek 2000; Banasiak 2001; Tomlinson, Zacharias 2001). The main purpose of this work is finding out the reason for such difference. In both systems the identity of primordia initiated by SAM changes periodically - primordia of the winter bud scales are produced in between the needle primordia of two consecutive annual increments of shoot axis. Therefore the change in primordia identity seems to have no connection with SAM executing organogenesis either autonomously or under the influence of previous organographic order.

\section{MATERIAL AND METHODS}

Coniferous shoot is produced in annual cycles (Korody 1937; Kemp 1943; Parke 1959; Owens, Molder 1976; Bompar 1974; Zagórska-Marek 1985; Tomlinson, Zacha-
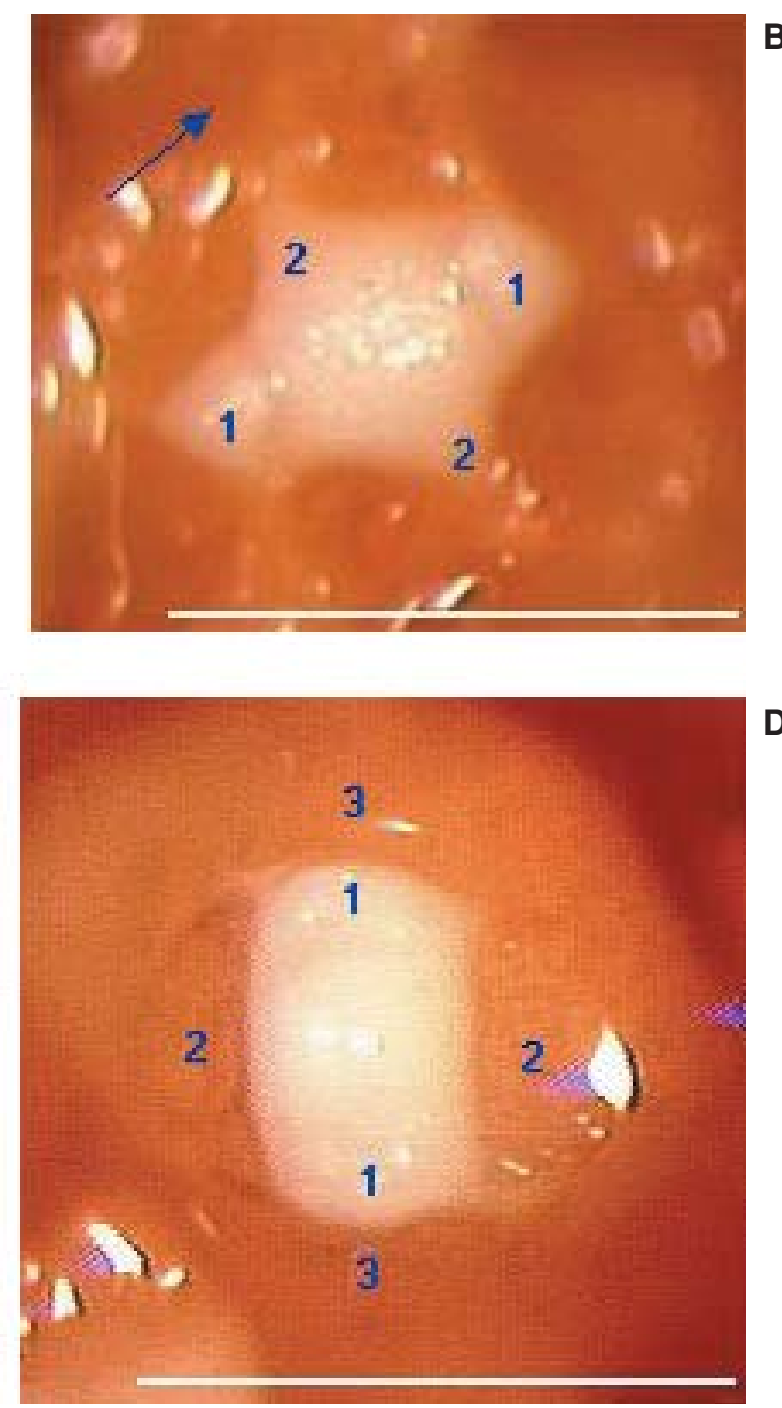

Fig. 2. Top view of live apices being in different stages of organogenesis. A-B Cephalotaxus fortunei; C-D Torreya nucifera; A-C the stage foliage leaf initiation; B-D the stage of bud scale initiation. Successive pairs of organ primordia are numberd. The arrow shows the direction of ontogenetic helix. Scale bar $-0.5 \mathrm{~mm}$. 
TABLE 1. Phyllotactic patterns found in examined species. Phyllotaxis was determined separately for each annual increment of the shoot axis. A new pattern for Torreya, which is trijugy of the main Fibonacci, is marked with bold type.

\begin{tabular}{|c|c|c|c|c|}
\hline \multirow{2}{*}{ Species } & \multirow{2}{*}{ Number of annual shoot increments } & \multirow{2}{*}{ Prevailing phyllotactic pattern } & \multicolumn{2}{|c|}{ Other phyllotactic patterns } \\
\hline & & & $(\%)$ & Type \\
\hline Abies concolor & 752 & $1: 2: 3: 5: 8 \ldots$ & 2.78 & $\begin{array}{l}2: 4: 6: 10 \ldots \\
1: 3: 4: 7: 11 \ldots \\
1: 2: 5: 7: 12 \ldots\end{array}$ \\
\hline Taxus baccata & 452 & $1: 2: 3: 5: 8 \ldots$ & 1.32 & $2: 4: 6: 10 \ldots$ \\
\hline Cephalotaxus fortune $i$ & 617 & $2: 4: 6: 10 \ldots$ & 11.19 & $\begin{array}{l}1: 2: 3: 5: 8 \ldots \\
1: 3: 4: 7: 11 \ldots\end{array}$ \\
\hline Torreya nucifera & 2671 & $2: 4: 6: 10 \ldots$ & 1.39 & $\begin{array}{l}1: 2: 3: 5: 8 \ldots \\
1: 3: 4: 7: 11 \ldots \\
\mathbf{3 : 6 : 9 : 1 5 \ldots .}\end{array}$ \\
\hline
\end{tabular}

TABLE 2. The comparisons of phyllotactic patterns and their chirality in pairs of successive annual increments. Axial homodromy is a case when both phyllotactic traits are the same in a pair. Transformation taking place within one increment is marked with bold type.

\begin{tabular}{|c|c|c|c|c|}
\hline Species & Number of comparisons & Axial homodromy (\%) & Transformations (\%) & Type of transformation \\
\hline Abies concolor & 443 & 98.34 & 1.35 & $\begin{array}{l}3 z: 4 s-2 s: 4 z \\
3 s: 4 z-2 s: 4 z \\
3 s: 4 z-2 s: 4 z \\
3 z: 5 s-4 z: 6 s\end{array}$ \\
\hline Taxus baccata & 257 & 96.90 & 0.39 & $3 z: 5 s-2 z: 3 s$ \\
\hline Cephalotaxus fortunei & 340 & 93.20 & 0.59 & $\begin{array}{l}2 z: 4 s-2 z: 3 s \\
2 s: 4 z-3 s: 5 z\end{array}$ \\
\hline Torreya nucifera & 1218 & 46.25 & 0.82 & $\begin{array}{l}2 z: 4 s-3 s: 4 z \\
2 s: 4 z-2 z: 3 s \\
2 z: 4 s-3 z: 6 s \\
2 z: 3 s-2 z: 4 s \\
3 z: 5 s-2 z: 4 s \\
2 z: 4 s-2 z: 3 s \\
2 z: 3 s-2 s: 4 z \\
2 s: 4 z-3 z: 6 s \\
3 z: 6 s-2 z: 4 s\end{array}$ \\
\hline
\end{tabular}

rias 2001). Single cycle begins from the stage of SAM's dormancy, during which the meristem, located on the top of embryonic shoot, rests within a winter bud. The shoot, sheltered by bud scales, is covered with preformed, tightly packed, foliage leaf primordia and is separated from differentiated tissues by colenchymatous plate, composed of 4-12 horizontal layers of isodiametric cells with thickened walls (Lewis, Dowding 1924). In a springtime young shoot grows out of the bud, its axis elongates and foliage leaves mature. These processes transform the embryonic shoot into fully elongated annual segment of the axis. In following two stages of the cycle SAM becomes active initiating at first the new winter bud's scale primordia and then, above them, the foliage leaf primordia for the next growing season. During the latest stage the colenchymatous plate is formed (Lewis, Dowding 1924; Kemp 1943; Parke 1959). The cycle ends with SAM entering winter dormancy. Cyclic activity of SAM results in a segmented axis, in which the narrow zone of bud scales with shortened internodes separates the successive regions occupied by foliage leaves. Plant material for comparative analysis has been collected from the trees growing in the Botanical Garden of Wrocław University, representing four species of conifers: Torreya nucifera (L.) Sieb. \& Zucc., Cephalotaxus fortunei
Hook, Taxus baccata L., Abies concolor (Gordon) Lindl. ex Hildebr. Among these Cephalotaxus and Torreya have been known from the literature as having typically bijugate phyllotaxis (Geyler 1867, cited in Namboodiri, Beck 1968; Barthelmess 1935; Fujita 1938; Camefort 1956; Namboodiri, Beck 1968).

Phyllotaxis of consecutive annual increments of collected shoots was determined by counting the numbers of contact parastichies. According to the protocol used in all our earlier papers the formula of contact parastichy pair (Adler 1974; Zagórska-Marek 1985) was supplemented with s and $\mathbf{z}$ indexes of parastichy orientation $\left(\mathbf{a}_{\mathbf{s}}: \mathbf{b}_{\mathbf{z}}\right)$. This allowed identification of the chiral configuration of the pattern. Terminal fragments of the shoots, isolated in different developmental stages of the annual cycle, were fixed in formalinaceto-alkohol, dehydrated, embedded in paraffin and sectioned either longitudinally or into the series of transverse sections $10 \mu \mathrm{m}$ thick. Sections were stained either with safranine and fast green or with Bismarck brown (Johansen 1940).

Measurements of the divergence angles were made on the series of transverse sections. Each series encompassed two successive annual increments covered with foliage leaves, separated by the bud scale zone. Successive sections of each series were photographed under Olympus light 
microscope with use of camera connected with Silicon Graphics workstation INDY. The divergence angles were measured on these images using computer program PHYL-2 (Matkowski et al. 1998). Departing vascular bundles or resin canals were treated as markers of the central points defining circumferential position of leaves and bud scales. The angles between them were measured continuously regardless the identity of pattern elements changing on borderlines of consecutive zones. This identity, which was not always conspicuous on a single section, has been carefully cross-checked by tracing each pattern element on consecutive sections to the level of its insertion. This level was anatomically different for a foliage leaf (clear parenchymatous pith) and for a bud scale (no parenchymatous pith).

\section{RESULTS}

\section{Phyllotactic patterns and their transformations in the successive zones of foliage leaves}

Summary of this survey is given in Table 1 and Table 2. In Taxus baccata and Abies concolor the dominant pattern was the main Fibonacci $(1,2,3,5,8 \ldots)$, in Cephalotaxus fortunei - bijugy of the main Fibonacci $(2,4,6,10 \ldots)$. In principle the pattern was, in all three species, repeated every year on the axis and its chiral configuration was maintained (Table 2). Transformations, rather infrequent, occurred mainly on the borderlines of annual increments. Only in Abies concolor they appeared sporadically within a single zone of foliage leaves. The chirality of phyllotaxis sometimes changed in a result of transformations. These were qualitative in nature, with Fibonacci pattern changing into any other helical pattern, such as Lucas $(1,3,4,7 \ldots$ ) or bijugy. Newly formed pattern was then continuing in a shoot for a number of consecutive years.

In Torreya nucifera the pattern occurring in the segments occupied by foliage leaves was almost exclusively bijugy of the main Fibonacci. The chirality of the pattern altered every year with $50 \%$ probability. Transformations occurred only on the borderlines of annual increments. In one case, trijugate pattern of the main Fibonacci $(3,6,9,15 \ldots$.$) , new$ for Torreya, was formed. It was maintained in a shoot for only one vegetative season. Next year, typical for Torreya bijugy was restored.

\section{Phyllotactic patterns in a zone of bud scales}

The zone of bud scales separating two consecutive zones of foliage leaves is usually too narrow to allow recognition of superficial contact parastichies. Therefore its phyllotaxis was analysed on the serial transverse sections, on which the divergence angles between consecutive pattern elements were measured.

In Abies concolor and Taxus baccata the main Fibonacci pattern, which was dominant in a zone of foliage leaves, usually persisted throughout the zone of bud scales (Figs 1A, 1B). Also in Cephalotaxus, where bijugate Fibonacci pattern prevailed, the same continuity was observed - the pattern was maintained even though the identity of initiated vegetative organs was not (Figs 1C, 2A, 2B).

Torreya did not follow the rule - organographic order in a zone of bud scales was different than in a zone of foliage leaves (Figs 1D, 1E, 2C, 2D). The pattern of bud scales was decussate, not chiral - whereas both patterns of foliage leaves, the older, formed before bud scales and the younger, following them, were bijugate with well defined chirality. Noticeably, the decussate pattern did not form rapidly, together with the change of organ identity, but more or less gradually (Figs 1E, 1F). It is possible that upper lateral buds, formed every year, such as these seen on figure 1D, promoted a quick start of the decussate mode (Fig. 1E). In the absence of the buds the decussate pattern of scales developed much more slowly (Fig. 1F).

\section{Morphology and topology of colenchymatous plate in a stage of winter dormancy}

The efficiency of anatomic, structural isolation of SAMs actively engaged in organogenesis, if different at all in the investigated species, might explain the autonomy of Torre$y a$ meristem. Therefore the degree of differentiation of colenchymatous plate in crucial stages of organogenesis and its position in relation to the foliage leaf zone and the bud scale zone were thoroughly investigated. In all studied species the colenchymatous plate visibly begins its differentiation when the first foliage leaf primordia for the next year are initiated. The plate is built of a few horizontal layers of thick-walled cells and shows rather small differences in morphology. These refer mainly to the number of layers, which may vary from 5 in Abies to 12 in Taxus and Torre$y a$. The number varies slightly in the population of individual shoots representing the same species. In Cephalotaxus, Taxus and Abies the margins of the crescent of colenchymatous plate in the cortical part of the shoot have always been reaching the border between last bud scales and the first new leaves of the embryonic shoot (Figs 3A-D). Thus it was positioned rather between the successive zones of scales and leaves, with most of the bud scales inserted below the plate.

In Torreya the position of the colenchymatous plate in a cortical part of the shoot was different. It was always much lower, with the plate situated at the level of uppermost bud scales or even encompassing the entire width of bud scale zone (Figs 3E, 3F).

The correlation between the position of the colenchymatous plate and the phyllotactic pattern in the bud scale zone was very clear. In these Torreya shoots where the thick plate extended through the whole region of bud scales, all scales were in the decussate pattern. In shoots where the plate was at the level of only a few youngest scale pairs (Figs 3E, $3 \mathrm{~F})$, only these pairs were in the decussate pattern. The bud scales below the plate were spirally arranged. Also in Abies, Taxus and Cephalotaxus where the bud scales in principle were inserted below the plate (Figs 3A-D) phyllotaxis of scales was spiral, the same as of foliage leaves.

\section{The position of procambium and protoxylem in a stage of winter dormancy}

In all studied species the procambial strands penetrated colenchymatous plate and the embryonic shoot in a stage of bud dormancy (Figs 3B-F). Their arrangement was regular and overall architecture was the same as that of the future pattern of differentiated primary vascular tissues. Noticeably the differentiated protoxylem, at the stage of winter dormancy, occurred only below the colenchymatous plate (Figs 3D-F) or penetrated it very slightly (Figs 3A-C). Protoxylem never passed through the whole width of col- 

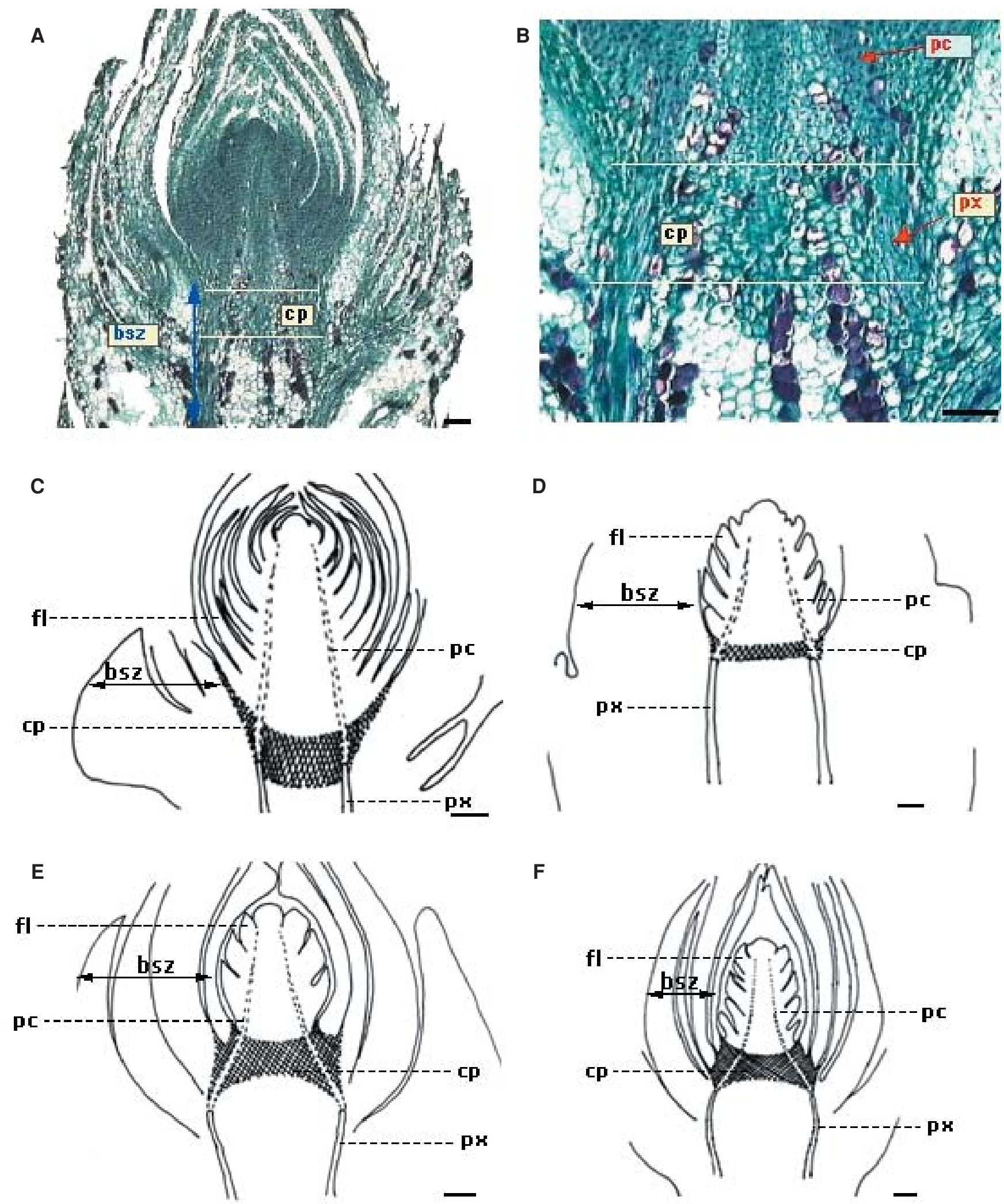

$\mathbf{F}$

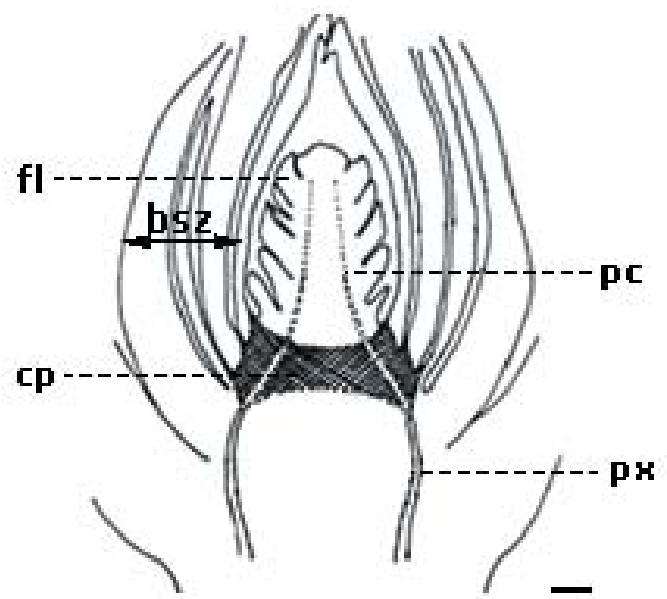

Fig. 3. Central longitudinal sections and the schemes of such sections through the winter bud. A, B - Cephalotaxus fortunei, C - Taxus baccata, D - Abies concolor, E, F - Torreya nucifera. bsz - bud scale zone, fl - foliage leaves, $\mathrm{cp}$ - colenchymatous plate, pc - procambium, px - protoxylem. Scale bar - $0.5 \mathrm{~mm}$.

lenchymatous plate and thus never entered the embryonic shoot at this developmental stage (Figs 3A-F).

The next visible correlation was between the differentiated protoxylem and phyllotactic pattern in a zone of bud scales and this seemed to be very interesting. In Cephalotaxus, Taxus and Abies the protoxylem was close to the colenchymatous plate or partially penetrated it. As already mentioned, in these species the colenchymatous plate is located above the bud scale zone (Figs 3A-D) therefore the differentiated protoxylem was associated with all bud scales and the entire zone had spiral phyllotaxis being in continuity with the pattern existing below in the zone of foliage leaves. The differentiated protoxylem in Torreya occurred always below the colenchymatous plate (Figs $3 \mathrm{E}, 3 \mathrm{~F}$ ). 


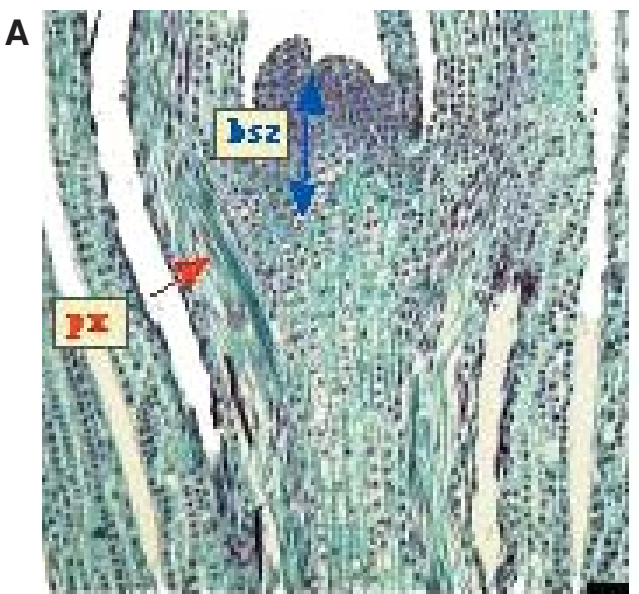

C

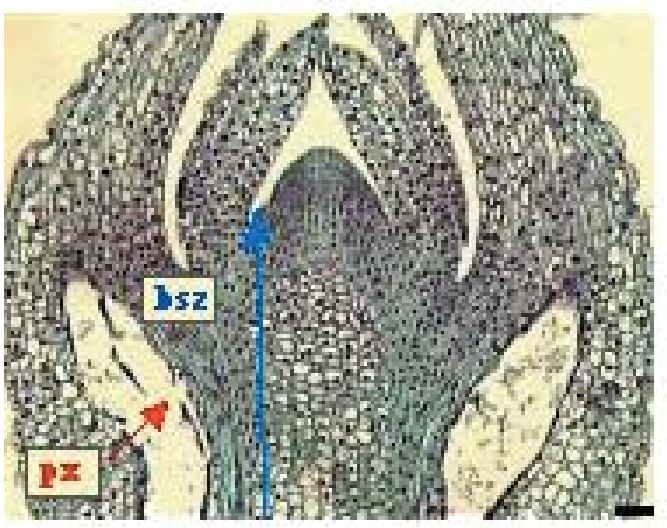

E

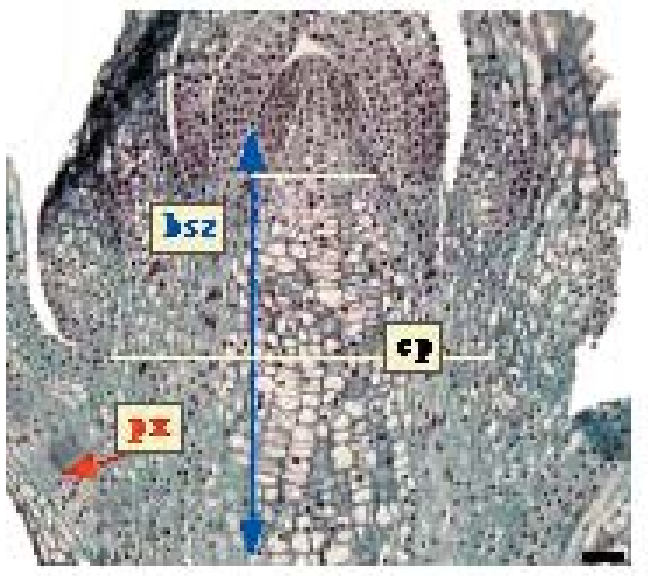

G

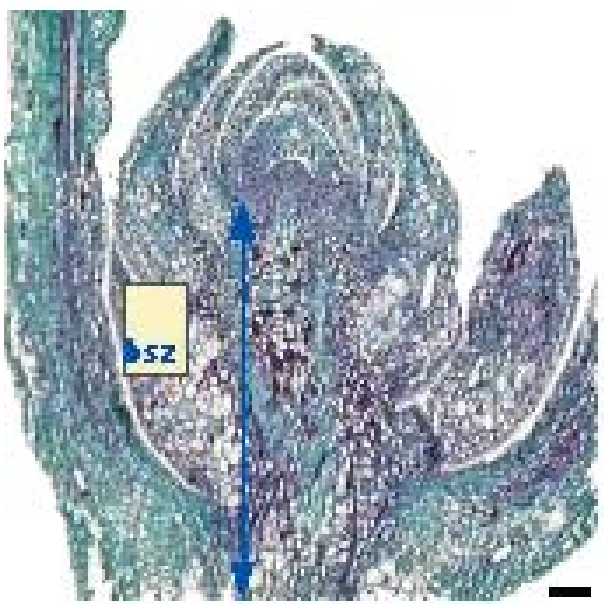

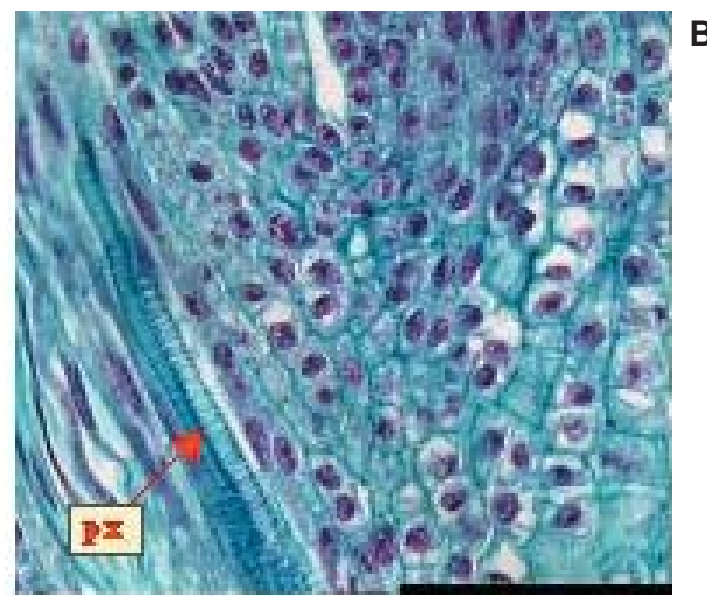
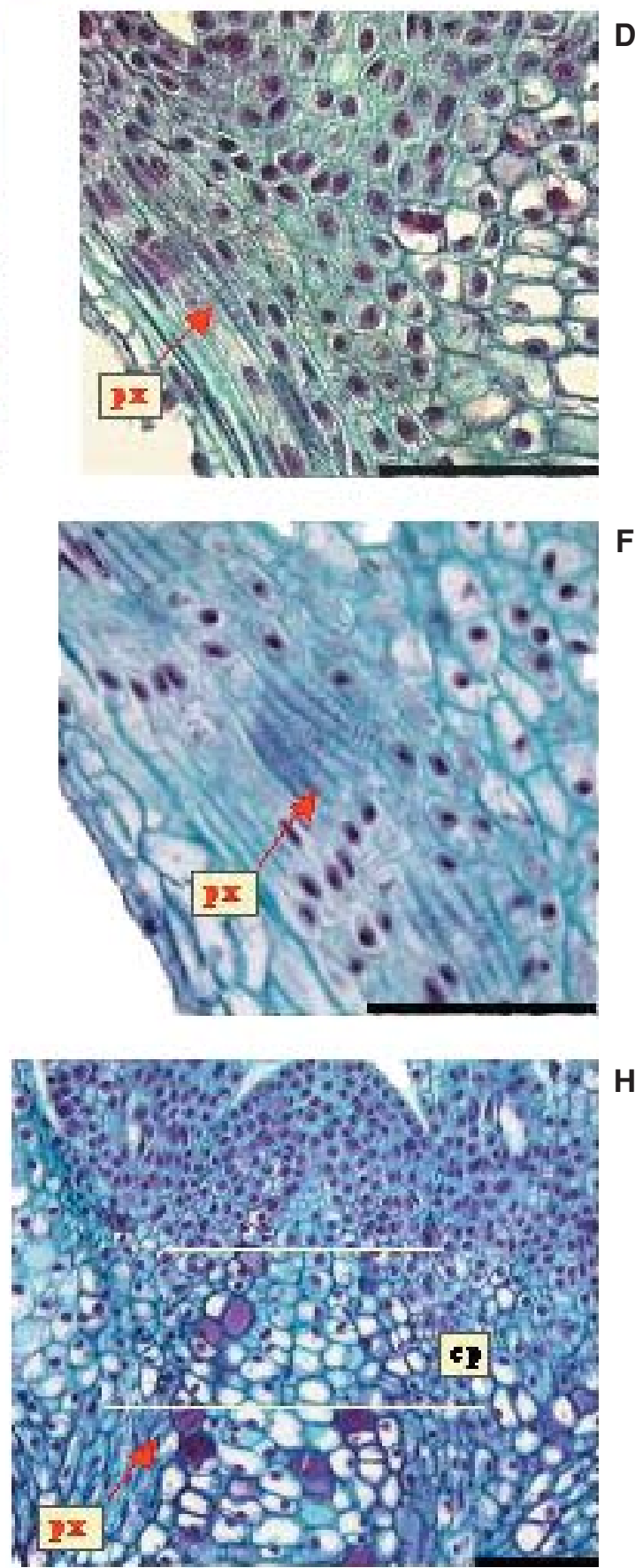

Fig. 4. Central longitudinal sections through the vegetative shoots being in different developmental stages. A-F Torreya nucifera: A-B the stage of initiation of the first pair of bud scales; C-D the stage of initiation of the second pair of bud scales; E-F the stage of initiation of the first foliage leaves. G-H Cephalotaxus fortunei: the stage of initiation of the first pair of foliage leaves. bsz - bud scale zone, px - protoxylem, cp - colenchymatous plate. Scale bar $-0.5 \mathrm{~mm}$. 
The plate's highest position ever observed was at the level of only few youngest bud scales (Figs 3E, 3F). Protoxylem was therefore in a close contact with only these bud scales that were inserted below the level of the plate. Regardless their number the scales being in contact with protoxylem had spiral arrangement, the same as foliage leaves from below. All bud scales inserted at the level of colenchymatous plate always had a decussate phyllotaxis.

\section{Ontogenetic changes of the protoxylem positioning} in relation to the initiation place

After winter dormancy the embryonic shoot starts elongating and the rapid differentiation of procambium above the colenchymatous plate takes place. In the next stage SAM starts initiation of new primordia. These will become the bud scales of the new winter bud. At this moment in all investigated species the youngest elements of differentiated protoxylem are very close to the organogenic zone of the SAM (Figs 4A, 4B). In Cephalotaxus, Taxus and Abies this connection is maintained during initiation of all bud scales. The protoxylem differentiates fast and always remains in a close contact with the initiation place. Also when the primordia of the first foliage leaves start appearing, the protoxylem is still close to their initiation place (Figs 4G, 4H). From this moment differentiation of protoxylem is halted and the formation of colenchymatous plate begins.

In Torreya, after the appearance of the first pair of bud scales, the rate of initiation of subsequent primordia becomes much faster than the rate of protoxylem differentiation. In consequence the distance between the last mature protoxylem element and the initiation place increases (Figs $4 \mathrm{C}-\mathrm{F})$. It reaches its maximum when the first primordia of foliage leaves are formed. When they appear, well below them, protoxylem ends its differentiation and colenchymatous plate is formed.

\section{DISCUSSION}

One of the most important questions concerning SAM is the degree of its autonomy in positioning primordia. Is the initiation site determined by the meristem itself or it is influenced by the signal flowing from differentiated tissues? The Torreya case clearly shows that there is no disjunction between the two alternatives. The same apex may execute either mode depending upon developmental stage. A significant increase in phenotypic plasticity of the shoot structure is the result.

We interpret our data in a following way: in coniferous shoot the mature protoxylem, the architecture of which parallels phyllotactic order, is a source of signals: 1) having a potential to determine initiation site at SAM, 2) flowing acropetally, in a polar way, to the apex surface. As long as these signals reach the organogenic zone of SAM, the primordia initiation sites are determined by preexisting pattern, assuring its continuity even when the identity of primordia changes and thus probably also changes their size and overall geometric relations to the size of organogenic surface, on which they are formed. In absence of the signals (as it is in Torreya when the distance between protoxylem and the surface of growing apex increases) SAM enters the alternative mode of executing organogenesis - it becomes fully autonomous in the process. Because, most probably, the primordia of bud scales are different in size their spacing is also different than that of foliage leaf primordia. Similarly in a floral apex of Magnolia changing size of primordia is postulated to be responsible for rich variety of phyllotactic patterns (Zagórska-Marek 1994; Zagórska-Marek, Stoma 2005). Most interestingly postulated autonomy of SAM in Torreya explains not only the formation of a decussate phyllotaxis in a bud scale zone but also the nature of bijugate pattern returning when the identity of primordia changes again from this of bud scales to that of new foliage leaves. The chiral configuration of bijugy is established at random, which proves that the pattern is formed independently from that, which existed before.

Besides the higher degree of phenotypic plasticity there is yet another advantage of the unique developmental strategy of Torreya. If undesirable pattern is formed, due to ontogenetic transition, the meristem can easily get rid of it. Trijugy, never reported before for Torreya, lasted only one year. Lower degree of SAM's autonomy in other than Torreya conifers explains the opposite phenomenon described earlier in Abies balsamea, where due to phyllotactic transitions, the resulting patterns, different from most commonly occurring, lasted sometimes for many years (Zagórska-Marek 1985). Many studies indicate that the quality of phyllotactic pattern has the genetic basis (Battjes at al. 1993; Zagórska-Marek 1994). Genes undoubtedly control the proportions between the primordia size and the size of organogenic surface at SAM and limit this way phyllotactic spectrum. Still the tolerance for solutions different from the species-specific norm remains an open question. Abnormal cell proliferation observed in SAMs of some mutants of model plant systems such as Arabidopsis often results in a loss of order and chaotic distribution of lateral organs (Medford et al. 1992; Fletcher et al. 1999).

The nature of the signal flowing acropetally from protoxylem is unknown. It can be auxin permeating from the cambial zone to the xylem elements and after becoming canalized moving upward together with the stream of ascending water. That the hormone plays crucial role in regulating SAM's organogenic activity has been demonstrated in many classical experiments with the auxin itself and its inhibitors such as TIBA and NPA (Snow, Snow 1937; Dostál 1952; Wardlaw 1955; Meicenheimer 1981).

The interest in auxin and phyllotaxis has been revived at present by works of Reinhardt and others (2000), who showed that exogenous application of auxin on the apex organogenic surface might promote initiation of new primordium in the location not predicted by phyllotaxis executed by SAM. Acropetal transport of IAA has already been considered as a factor regulating pattern of procambial differentiation, affecting organogenesis (Avsian-Kretchmer at al. 2002).

Whether indeed the Torreya SAM, isolated from putative signals flowing acropetally from the vascular system, changes phyllotaxis regularly between the decussate and bijugate pattern only because of the differences in size of primordia of bud scales and of foliage leaves - remains to be seen. Such possibility is suggested by the results of computer simulations and by this what can be seen on figures $2 \mathrm{C}$, 2D. This research is in progress. 


\section{LITERATURE CITED}

AVSIAN-KRETCHMER O., CHENG J.C., CHEN L., MOCTEZUMA E., SUNG Z.R. 2002. Indole Acetic Acid Distribution Coincides with Vascular Differentiation Pattern during Arabidopsis Leaf Ontogeny. Plant Physiol. 130: 199-209.

ADLER I. 1974. A model of contact pressure in phyllotaxis. J. Theor. Biol. 45: 1-79

AIRY H. 1873. On leaf arrangement. Proc. R. Soc. Lon. 21: 176$-179$.

BANASIAK A.S., ZAGÓRSKA-MAREK B. 1998. Homodromia i antydromia osiowa w pędach roślin szpilkowych. In: Botanika Polska u progu XXI wieku. Materiały sympozjum i obrad sekcji 51 Zjazdu PTB, Gdańsk p. 20.

BANASIAK A.S., ZAGÓRSKA-MAREK B. 2000. Torreya case indicates autonomy of apical shoot meristem generating phyllotaxy. Am. J. Bot. (Suppl) p. 23.

BANASIAK A.S. 2001. Anatomiczne uwarunkowania osiowej homodromii i antydromii w pędach roślin szpilkowych. PhD Thesis. Wrocław University.

BARTHLMESS A. 1935. Über den Zusammenhang zwischen Blattstellung und Stelenbau, unter besonderer Berücksichtigung der Koniferen. Bot. Arch. 37: 207-260.

BATTJES J., CHAMBERS K.L., BACHMANN K. 1994. Evolution of microsporangium number in Microseris pygmaea (Asteraceae: Lactucaceae). Am. J. Bot. 80: 419-428.

BOMPAR J.L. 1974. Morphologie et ontogenese du rameau plagiotrope du Cephalotaxus drupacea Sieb. et Zucc. Male. Rev. Gen. Bot. 81: 5-39.

CAMEFORT H. 1956. Étude de la structure du point végétatif et des variations phyllotaxiques chez quelques Gymnospermes. Ann. Sci. Nat. Bot. Biol. Veg. XI, 17: 1-185.

DOSTÁL R. 1952. Experimental morphogenesis of buds in the horsechestnut (Aesculus hippocastanum L.). Moravskoslezké Akad. věd Přirodnich, Práce 24: 109-146. In: Czech with English summary.

DOUADY S., COUDER Y. 1996. Phyllotaxis as a dynamical self organizing process. Part I. The spiral modes resulting from time-periodic iterations. J. Theor. Biol. 178: 255-274.

FLEMING A.J., McQUEEN-MASON S., KUHLEMEIER C. 1997. Induction of leaf primordia by the cell wall protein expansin. Science 276: 1415-1418.

FLETCHER J., BRAND U., RUNNING M., SIMON R., MEYEROWITZ E. 1999. Signaling of cell fate decisions by CLAVATA3 in Arabidopsis shoot meristems. Science 283: 1911-1914.

FUJITA T. 1938. Statistiche Untersuchung über die Zahl der konjugierten Parastichen bei den schraubigen Organstellungen. Bot. Mag. 52: 425-433.

GEYLER H.T. 1867. Über den Gefässbündelverlauf in den Laubblattregionen der Coniferen. Jahrb. Wiss. Bot. 6: 55-208.

GIROLAMI G. 1953. Relation between phyllotaxis and primary vascular organization in Linum. Am. J. Bot. 40: 618-625.

HOFMEISTER W. 1968. Allgemeine Morphologie der Gewachse. In: Handbuch der Physiologischen Botanik. Bary A. de, Irmisch T.H., Sachs J. (ed.). Leipzig: Engelmann, 405-664.

JOHANSEN D.A. 1940. Plant Microtechnique. McGraw-Hill, New York, London.

JÖNSSON H, HEISLER M.G., SHAPIRO B.E., MEYEROWITZ E.M., MJOLSNESS E. 2006. An auxin-driven polarized transport model for phyllotaxis. PNAS 5: 1633-1638.

KEMP M. 1943. Morphological and ontogenetic studies on Torreya californica. I. The vegetative apex of the megasporangiate tree. Amer. Jour. Bot. 30: 504-517.

KORODY E. 1937. Studien am Spross-Vegetationspunkt von Abies concolor, Picea excelsa, und Pinus montana. Beitr. Biol. Pflanz. 25: 23-59.

LARSON P.R. 1975. Development and organization of the primary vascular system in Populus deltoides according to phyllotaxy. Am. J. Bot. 62: 1084-1099.
LARSON P.R. 1977. Phyllotactic transitions in the vascular system of Populus deltoides Bartr. as determined by $14 \mathrm{C}$ labeling. Planta 134: 241-249.

LEWIS F.J., DOWDING E.S. 1924. The anatomy of the buds of Coniferae. Ann. Bot. 38: 217-228.

MATKOWSKI A., KARWOWSKI R., ZAGÓRSKA-MAREK B. 1998. Two algorithms of determining the middle point of the shoot apex by surrounding organ primordia positions and their usage for computer measurements of divergence angles. Acta Soc. Bot. Pol. 67: 151-159.

MEDFORD J.I., BEHRINGEN F.J., CALLOS J.D., FELDMAN K.A. 1992. Normal and Abnormal Development in the Arabidopsis Vegetative Shoot Apex. Plant Cell 4: 631-643.

MEICENHEIMER R.D. 1981. Changes in Epilobium phyllotaxy induced by N-1-Naphthylphthalamic Acid and alfa-4-Chlorophenoxyisobutyric Acid. Am. J. Bot. 68: 1139-1154.

NAMBOODIRI K.K., BECK C.B. 1968. A comparative study of the primary vascular system of conifers. I. Genera with helical phyllotaxis. Am. J. Bot. 55: 447-457.

OWENS J.N., MOLDER M. 1976. Bud development in Sitka spruce. I. Annual growth cycle of vegetative buds and shoots. Can. J. Bot. 54: 313-325.

PARKE R.V. 1959. Growth periodicity and the shoot tip of Abies concolor. Am. J. Bot. 46 (2): 110-118.

REINHARDT D., MANDEEL T., KUHLEMEIER C. 2000. Auxin regulates the initiation and radial position of plant lateral organs. Plant Cell 12: 507-518.

REINHARDT D., PESCE E.R., STIEGER P., MANDEL T., BALTENSPERGER K., BENNETT M., TRAAS J., FRIML J., KUHLEMEIER C. 2003. Regulation of phyllotaxis by polar auxin transport. Nature 426: 255-260.

RICHARDS F.J. 1951. Phyllotaxis: quantitative expression and relation to growth in the apex. Phil. Trans. R. Soc. London S. B. 235: 509-563.

RIDLEY J.N. 1982. Packing efficiency in sunflower heads. Math. Biosc. 58: 129-139.

SCHWABE W.W., CLEWER A.G. 1984. Phyllotaxis - a simple computer mode based on the theory of a polarity - translocated inhibitor. J. Theor. Biol. 109: 595-619.

SNOW M., SNOW R. 1937. Auxin and leaf formation. New Phytol. 36: 283-300.

STIEGER P.A., REINHARDT D., KUHLEMEIER C. 2002. The auxin influx carrier is essential for correct leaf positioning. Plant J. 32: 509-517.

SCHWENDENER S. 1878. Mechanische Theorie der Blattstellungen. Leipzig, Engelmann.

SMITH R., GUYOMARC'H S., MANDEL., REINHARDT D., KUHLEMEIER C., PRUSINKIEWICZ P. 2006. A plausible model of phyllotaxis. PNAS 5: 1301-1306.

TOMLINSON P.B., ZACHARIAS E.H. 2001. Phyllotaxis, phenology and architecture in Cephalotaxus, Torreya and Amentotaxus (Coniferales). Bot. J. Linn. Soc. 135: 215-228.

VEEN A.H., LINDENMAYER A. 1977. Diffusion mechanism for phyllotaxis. Theoretical physico-chemical and computer study. Plant Physiol. 60: 127-139.

WARDLAW C.W. 1955. Responses of a fern apex to direct chemical treatments. Nature 176: 1098-1100.

ZAGÓRSKA-MAREK B. 1985. Phyllotactic patterns and transitions in Abies balsamea. Can. J. Bot. 63: 1844-1854.

ZAGÓRSKA-MAREK B. 1994. Phyllotactic diversity in Magnolia flowers. Acta Soc. Bot. Pol. 63: 117-137.

ZAGÓRSKA-MAREK B., STOMA S. 2005. What makes floral phyllotaxis in Magnolia diverse - a lesson from virtual garden. In: Book of Abstracts of the XVII International Botanical Congress. Vienna p. 308. 